\title{
Response of dual-purpose wheat to nitrogen fertilization and seed inoculation with Azospirillum brasilense
}

\section{Resposta de trigo de duplo-propósito à fertilização nitrogenada e inoculação das sementes com Azospirillum brasilense}

\author{
Mauricio Pase Quatrin ${ }^{1 *} \mathbb{D}$, Clair Jorge Olivo ${ }^{1} \mathbb{D}$, Gabriela Descovi Simonetti ${ }^{1} \mathbb{D}$, \\ Vinicius Felipe Bratz ${ }^{1} \mathbb{D}$, Guilherme Librelotto de Godoy ${ }^{1}$, Lucas Giovane Casagrande ${ }^{1} \mathbb{C}$
}

'Universidade Federal de Santa Maria/UFSM, Santa Maria, RS, Brasil

*Corresponding author: mauricio.quatrin@gmail.com

Received in December 4, 2018 and approved in May 6, 2019

\begin{abstract}
The use of inoculants containing plant growth-promoting bacteria is an alternative to increase the efficiency of nitrogen fertilizers. Studies evaluating the effects of inoculation on forage yield, straw yield, and grain yield in dual-purpose wheat cultivars are scarce. This study aimed to evaluate the forage yield and grain yield in dual-purpose wheat inoculated with Azospirillum brasilense and fertilized with increasing nitrogen rates during two agricultural years (2016-2017) under cutting management. The trial was carried out in a completely randomized block design with four replicates, using a $2 \times 4$ factorial arrangement. The factors were the inoculation (control or A. brasilense) and nitrogen rates $\left(0,50,100\right.$ and $150 \mathrm{~kg} \mathrm{ha}^{-1}$ of $\left.\mathrm{N}\right)$. Forage, grain and straw yield, and number of tillers were evaluated. Forage yield differed between treatments with inoculation and without inoculation, 3952 and $3350 \mathrm{~kg} \mathrm{DM} \mathrm{ha}^{-1}$, respectively. There was no effect of inoculation on grain yield. The forage and leaf biomass yield, the number of tillers and straw yield increased with inoculation.
\end{abstract}

Index terms: “BRS Tarumã” wheat; forage yield; grain yield; strains Ab-V5 and Ab-V6; Triticum aestivum.

\begin{abstract}
RESUMO
O uso de inoculantes contendo bactérias promotoras do crescimento vegetal é uma alternativa para aumentar a eficiência de uso dos fertilizantes nitrogenados. Em trigo de duplo propósito estudos avaliando a inoculação sobre a produção de forragem, palha e grãos são escassos. Nesse sentido, avaliou-se a produção de forragem e o rendimento de grãos em trigo de duplo propósito inoculado com Azospirillum brasilense e fertilizado com doses de nitrogênio, nos anos agrícolas de 2016 e 2017, em condições de corte. O delineamento experimental utilizado foi o de blocos ao acaso com quatro repetições, organizado em esquema fatorial. Os fatores foram a inoculação

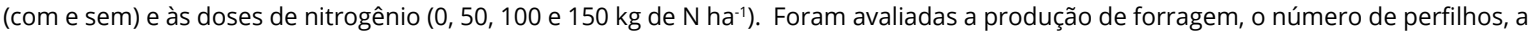
produção de palha e a produção de grãos. As médias de produção de forragem total diferiram entre os tratamentos com e sem inoculação 3952 e 3350 kg de MS ha-1, respectivamente. Não houve efeito da inoculação sobre a produção de grãos. A produção de forragem e de biomassa de lâminas foliares, o número de perfilhos e a produção de palha são incrementados com o uso da inoculação.
\end{abstract}

Termos para indexação: BRS Tarumã; produção de forragem; rendimento de grãos; estirpes Ab-V5 e Ab-V6; Triticum aestivum.

\section{INTRODUCTION}

Dual-purpose winter cereals, such as wheat, are an alternative to produce green fodder for feed livestock during autumn and early winter than other commonly used forage sources such as annual ryegrass (Lolium multiflorum Lam.) (Confortin et al., 2013). An advantage of this production system is that it allows greater flexibility, since the farmer may choose to optimize the production of forage or grains according to climatic conditions or grain prices. This flexibility might lead to higher income. However, it is necessary to consider some management techniques for successful cultivation of dual-purpose cereals, including the optimal moment for starting and finishing the grazing cycle, stocking rate, sward height and fertilization (Martin et al., 2010).

The adequate nutrient supply, mainly nitrogen $(\mathrm{N})$, is fundamental to maximize the yield and nutritive value of forage, recovery of leaf area and grain yield (Pavinato et al., 2014). Then, synthetic nitrogen fertilizers are used, although they increase production costs and contribute to greenhouse gas emissions (Costa et al., 2015). Increases in N fertilization 
rates aiming at achieving high forage and grain yields also imply negative environmental impacts, since a large part of $\mathrm{N}$ applied is lost through leaching, volatilization and denitrification processes (Zaman et al., 2016).

The use of inoculants containing plant growthpromoting bacteria stands out as an alternative to decrease the use of nitrogen fertilizers (Piccinin et al., 2013). These bacteria can establish an association with plants by colonizing the rhizosphere, roots and internal tissues, stimulating plant growth through the synthesis of phytohormones (Moreira et al., 2010). This group of microorganisms can also perform biological nitrogen fixation (BNF) in association with different plant species, transferring part of the fixed N (Carvalho et al., 2014). Among the most studied types of diazotrophic bacteria, Azospirillum is highlighted by its positive effects on root development, water and nutrient absorption, and BNF, when associated with grasses (Hungria et al., 2010).

In this regard, the use of inoculation with the bacteria of the genus Azospirillum can partially replace nitrogen fertilization of dual-purpose wheat. However, research results evaluating the yield of wheat inoculated with Azospirillum brasilense have been varied both at low and high rates of nitrogen fertilization (Silva; Pires, 2017; Alves et al., 2017; Piccinin et al., 2013; Galindo et al., 2017). Furthermore, studies evaluating plant growth-promoting microorganisms as seed inoculants have mostly concentrated their focus on genotypes recommended exclusively for grain production. This study aimed to evaluate the dual-purpose "BRS Tarumã" wheat submitted to inoculation with Azospirillum brasilense (strains Ab-V5 and Ab-V6) and different nitrogen rates on forage yield and grain yield in the agricultural years of 2016 and 2017.

\section{MATERIAL AND METHODS}

The trial was performed during two agricultural years (2016 and 2017) at the Dairy Cattle Laboratory of the Federal University of Santa Maria, located in the central depression of Rio Grande do Sul (altitude of $95 \mathrm{~m}$ above sea level, latitude $29^{\circ} 43^{\prime}$ 'S and longitude 53 $42^{\prime} \mathrm{W}$ ), Brazil. The soil is classified as a Hapludalf Paleudult (Soil Survey Staff, 2014). According to the classification of Köppen, the climate is humid subtropical (Cfa). Mean precipitation and temperature data during the experimental period were obtained from the Meteorological Station the Federal University of Santa Maria, located approximately $700 \mathrm{~m}$ apart from the experimental area (Figure 1). Soil analysis data $(0-20 \mathrm{~cm}$ depth) before the trial were as follows: pH in $\mathrm{H}_{2} \mathrm{O}$ : 6.0; OM: $2.7 \%$; $\mathrm{P}$ in Mehlich: $24.8 \mathrm{mg} \mathrm{dm}^{-3}$; $\mathrm{K}: 0.757 \mathrm{cmol}_{\mathrm{c}} \mathrm{dm}^{-3}$; $\mathrm{Ca}: 5.80 \mathrm{cmol}_{\mathrm{c}} \mathrm{dm}^{-3} ; \mathrm{Mg}: 2.7 \mathrm{cmol}_{\mathrm{c}}$ $\mathrm{dm}^{-3}$; CEC: $12.7 \mathrm{cmol}_{\mathrm{c}} \mathrm{dm}^{-3}$, respectively.

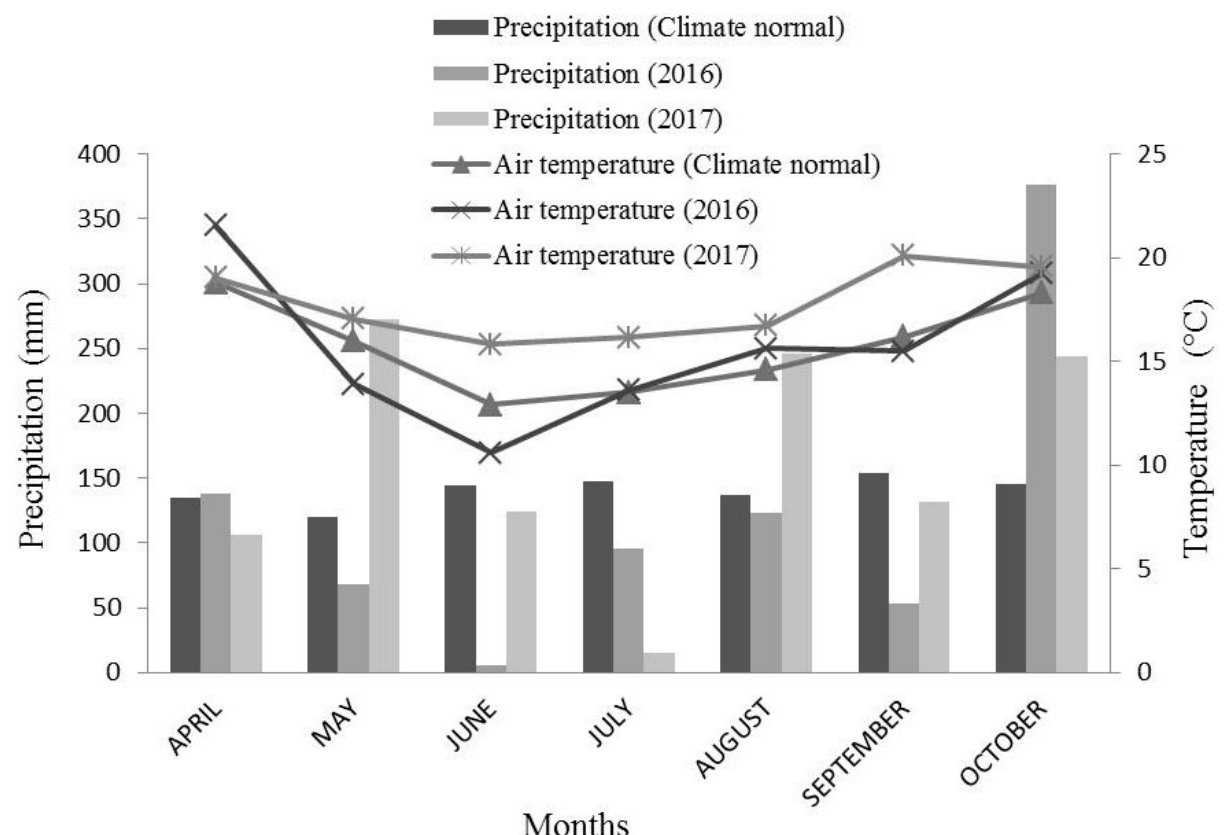

Figure 1: Climate normals for precipitation and temperature in Santa Maria, RS and precipitation and temperature during the agricultural years of 2016 and 2017 (April to October). 
Before sowing, in both years, the soil was prepared by harrowing. The basal fertilization comprised $45 \mathrm{~kg} \mathrm{ha}^{-1}$ of $\mathrm{P}_{2} \mathrm{O}_{5}$ and $30 \mathrm{~kg} \mathrm{ha}^{-1}$ of $\mathrm{K}_{2} \mathrm{O}$. The experimental area was divided into 32 plots $(4 \times 3 \mathrm{~m})$ and $1 \mathrm{~m}$ wide access corridors. The trial was carried out in a completely randomized block design with four replicates, using a 2 (qualitative) $\mathrm{x} 4$ (quantitative) factorial arrangement. The terrain slope served as a blocking criterion. The qualitative and quantitative factors corresponded to the use or not of inoculation and $\mathrm{N}$ rates $\left(0,50,100\right.$ and $150 \mathrm{~kg}$ of $\left.\mathrm{N} \mathrm{ha}^{-1}\right)$, respectively.

The sowing was performed on April 20, 2016, and April 12, 2017. One week before sowing the seeds were treated with fungicide (Difeconazol - $150 \mathrm{~g} / \mathrm{L}$ ) and insecticide (Tiametoxam - $350 \mathrm{~g} / \mathrm{L}$ ). Approximately two hours before sowing, seeds were inoculated with the commercial product AzoTotal ${ }^{\circledR}$ - liquid inoculant (bacterium Azospirillum brasilense in pure culture, strains $\mathrm{Ab}-\mathrm{V} 5$ and $\mathrm{Ab}-\mathrm{V} 6$, with a concentration of $2.0 \times 10^{8} \mathrm{CFU} /$ $\mathrm{mL}$ ). The inoculant was applied at $5 \mathrm{~mL}$ of the commercial product per kg of seed. Seeds were sowed in rows spaced $17 \mathrm{~cm}$ apart, using a seed drill. The recommended sowing density was 400 viable seeds per $\mathrm{m}^{2}$, totaling about 120 $\mathrm{kg}$ of seeds per ha.

Urea $(46 \% \mathrm{~N})$ was used as the nitrogen source. Nitrogen fertilization was equally divided into four applications, according to each treatment, in which the first application occurred 30 days after sowing, and the remaining applications were performed after each cutting. The evaluated variables were: forage mass and its structural components (upper and lower stratum), forage yield, leaf biomass yield, number of tillers per $\mathrm{m}^{2}$, number of ears per $\mathrm{m}^{2}$, number of grains per ear, grain yield, hectoliter weight (HW) and mass of one thousand grains.

The plots were managed under cutting. The criterion to begin cutting was the sward height, approximately 20 $\mathrm{cm}$, measured using a graded ruler and transparency (acetate sheet) with $0.3 \times 0.2 \mathrm{~m}$ and approximate weight of $25 \mathrm{~g}$. Four cuttings per plot were made close to the ground using a $0.25 \times 0.25 \mathrm{~m}$ square. After sampling, the plots were cut with the aid of a lawnmower adapted to a residual height of approximately $10 \mathrm{~cm}$, removing the material by using rakes. Then, four additional cuttings were made close to the ground to determine the residual forage mass (lower stratum). All samples were weighed to determine the forage mass in the lower and upper stratum (forage mass from cuttings made close to the ground minus forage mass in the lower stratum). Subsequently, the samples were mixed, and a subsample was taken for evaluation of the morphological composition of the wheat (upper and lower stratum). The subsample was manually separated into leaf blade, stem + sheath, and senescent material. These components were oven-dried in a forcedair oven at $55^{\circ} \mathrm{C}$ until constant weight to determine the pre-dried mass of each component. Forage yield in the first cutting corresponded to the available mass of the respective cutting. The forage yields in the second and third cuttings were determined by subtracting the forage mass in the upper stratum (corresponding cutting) from the forage mass in the lower stratum (previous cutting). Total forage yield was obtained by the sum of forage yield of all cuttings. The same procedure was adopted to calculate leaf biomass yield but using the variable leaf biomass. The number of tillers per $\mathrm{m}^{2}$ was counted in two points per plot before the second and third cuttings. Each point corresponded to a $20-\mathrm{cm}$ segment of the sowing row.

Wheat height at the first node, which corresponds to the apical meristem, was monitored in each cutting. When it reached a height of approximately $10 \mathrm{~cm}$, the cuttings were interrupted, and the plots were deferred to allow grain production. Preventive fungicide applications (Trifloxystrobin - $100 \mathrm{~g} / \mathrm{L}$ and Tebuconazole - $200 \mathrm{~g} / \mathrm{L}$ ) were made from the boot stage until after the start of grainfilling. Spraying was performed 48 to 24 hours before rainfall occurrence.

Manual harvesting of the useful area of each plot was done to estimate grain yield. The material harvested was threshed to evaluate the grain yield, hectoliter weight and the mass of one thousand grains adjusted to the standard moisture of $13 \%$. At harvesting, a sample of two central rows ( $1 \mathrm{~m}$ long) of each plot, corresponding to an area of $0.34 \mathrm{~m}^{2}$, was collected close to the ground. The material from this cutting was used to determine the number of ears per $\mathrm{m}^{2}$, number of grains per ear and straw yield. The number of ears in each sample was determined by counting and converting to $\mathrm{m}^{2}$. The number of grains per ear was determined by the mean number of grains in 15 ears randomly chosen per sample. The straw yield was determined from the separation between grains and the straw mass. The straw obtained was oven-dried to constant weight and then weighed.

The data were submitted to analysis of variance by the Fisher-Snedecor's $F$ test at $5 \%$ probability to error. Polynomial regression analysis was performed when at least one significant effect was found. The coefficients of determination $\left(\mathrm{r}^{2}\right)$ and the significance value $(\mathrm{P})$ were used as criteria for choosing the model. Curves were adjusted for the inoculation as a function of $\mathrm{N}$ rates. All variables were submitted to Pearson's correlation analysis. The agricultural year was included as a random effect in the model due to the impossibility of repeating the environmental conditions over 
time. The analyzes were performed using SAS software, University Edition. The statistical model was used as follows: Yijk $=\mu+\mathrm{Ii}+\mathrm{Nj}+\mathrm{INij}+\mathrm{Bk}+\varepsilon i j k$, in which Yijk, represents the dependent variables; $\mu$, is the overall mean; $\mathrm{Ii}$, is the effect of inoculation ( $\mathrm{i}=2)$; $\mathrm{Nj}$, is the effect of $\mathrm{N}$ rates $(\mathrm{j}=4) ; \mathrm{IiNj}=$ is the interaction between inoculation and $\mathrm{N}$ rates; $\mathrm{Bk}$, is the effect of blocks and $\varepsilon \mathrm{ijk}$ is the random error associated with the i-inoculation, $\mathrm{j}$-nitrogen rates, and k-block.

\section{RESULTS AND DISCUSSION}

A sward height of $20 \mathrm{~cm}$ was used as the criterion for the starting of cuttings at $10 \mathrm{~cm}$ above the soil allowed three cuttings in all plots, in June, July and August of both years (2016 and 2017). Cutting intervals from the first use were on average 28 days. Cutting cycles of approximately 28 days are associated with greater forage yield and leaf biomass yield in dual-purpose winter cereals (Meinerz et al., 2012).

Regarding forage mass and grain yield, there was no interaction between $\mathrm{N}$ rates and inoculation. Then, the results of quantitative and qualitative factors are described alone.
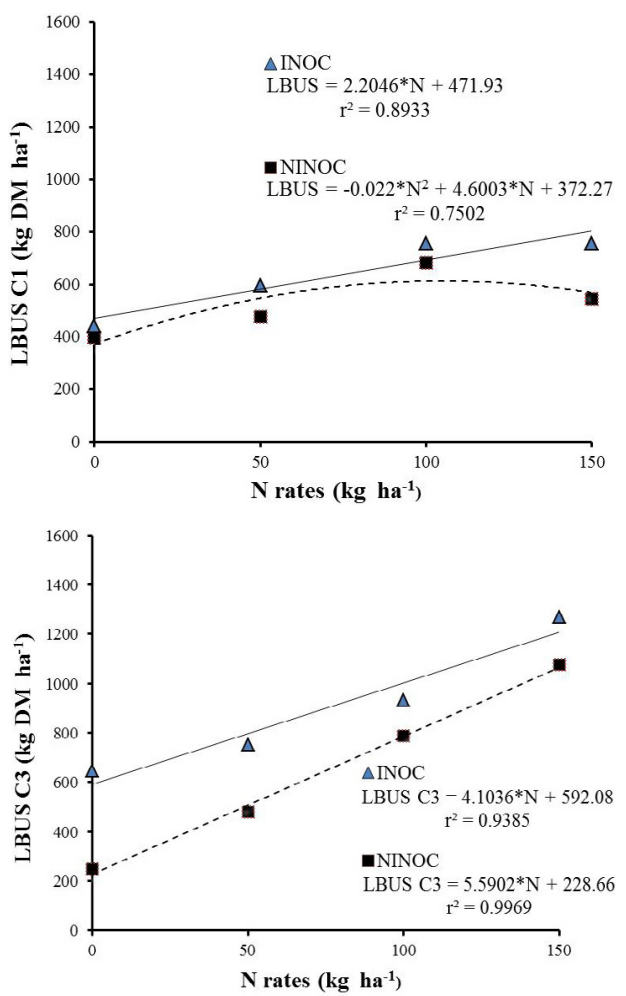

A linear increase in forage mass in the upper stratum with increasing $\mathrm{N}$ rates was observed for both non-inoculated $\left(\mathrm{y}=3.25^{*} \mathrm{~N}+478.8, \mathrm{r}^{2}=0.88, \mathrm{P}=0.001\right)$ and inoculated wheat $\left(\mathrm{y}=3.03 * \mathrm{~N}+712, \mathrm{r}^{2}=0.97, \mathrm{P}=0.005\right)$. Inoculation increased forage mass in the upper stratum by approximately $25 \%$ in all nitrogen rates. There was a quadratic effect of non-inoculated wheat on leaf biomass (Figure 2) in the first cutting. It should be noted that there was a decline in forage mass at the highest $\mathrm{N}$ rate $\left(150 \mathrm{~kg} \mathrm{ha}^{-1}\right)$ compared to fertilization with $100 \mathrm{~kg} \mathrm{~N} \mathrm{ha}^{-1}$. On the other hand, there was a linear increase in leaf biomass with increasing $\mathrm{N}$ rates for inoculated wheat. The same behavior was observed in the second and third cuttings in response to increasing $\mathrm{N}$ rates. The mean leaf biomass responded linearly to $\mathrm{N}$ rates when considering all cuttings. The use of $A$. brasilense increased leaf biomass by 24.7 and $13.3 \%$ in wheat without and with fertilization $\left(150 \mathrm{~kg} \mathrm{~N} \mathrm{ha}^{-1}\right)$.

There was no effect $(\mathrm{P}>0.05)$ of the qualitative and quantitative factors on stem mass and senescent material mass in the upper stratum. The mean values obtained were 187 and $80.5 \mathrm{~kg} \mathrm{DM} \mathrm{ha}^{-1}$, corresponding to a proportion of 22.5 and $9.6 \%$ in the forage mass, respectively.
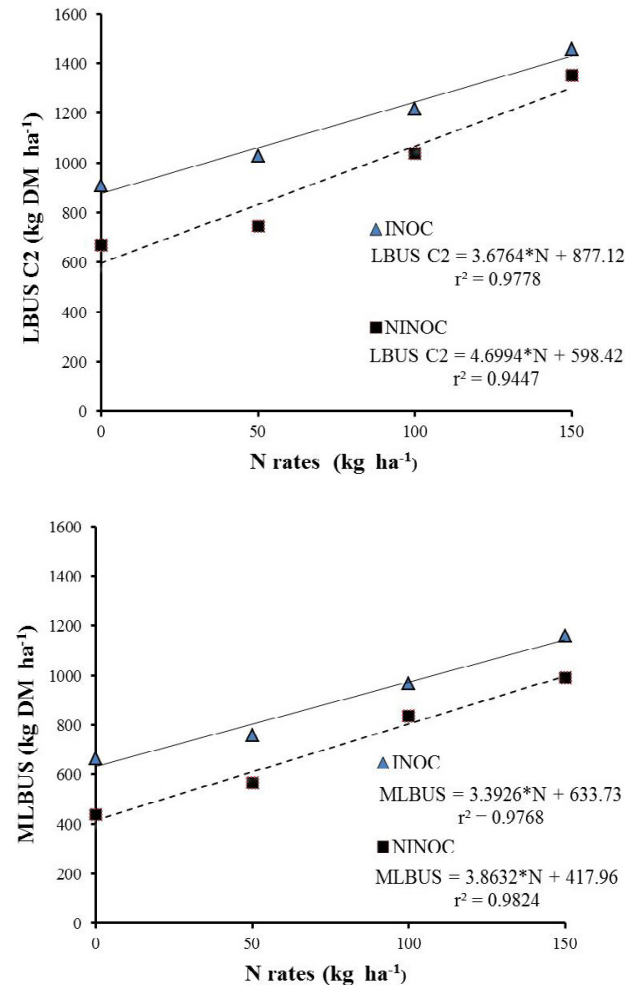

Figure 2: Leaf biomass in the upper stratum in the first (LBUS C1), second (LBUS C2) and third (LBUS C3) cuttings and mean leaf biomass (all cuttings; MLBUS) in dual-purpose wheat inoculated or not with Azospirillum brasilense and fertilized with increasing nitrogen rates. Agricultural years of 2016 and 2017. INOC = inoculated; NINOC = non-inoculated. 
Relative to the lower stratum, there was a linear increase in forage mass, leaf biomass and stem mass with increasing $\mathrm{N}$ rates (Figure 3 ) in the first and third cuttings, with no effect of inoculation. These results are related to an increase of stem size, the number of leaves and tillers when nitrogen is highly available in the soil for wheat (Ferreira et al., 2017).

The highest proportion of leaf blades after the cuttings, when associated to $\mathrm{N}$ rates, is fundamental for satisfactory regrowth since the period required for the regrowth depends on the remaining leaf blade area. Thus, the higher the proportion of this component, the less time it takes for the plant to reach maximum photosynthetic efficiency again (Bryant; Gregorini; Edwards, 2012).

Regarding the stem mass and senescent material mass in the lower stratum, no effects of qualitative and

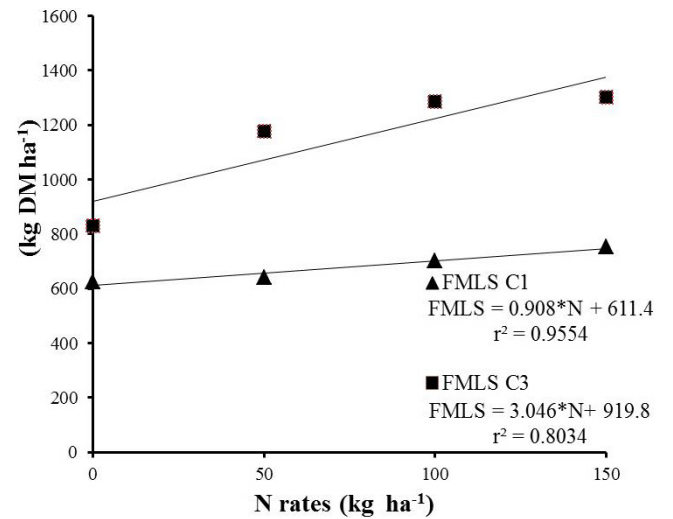

quantitative factors were observed. The mean values obtained for stem mass and senescent material mass in the lower stratum were 339 and $177 \mathrm{~kg} \mathrm{DM} \mathrm{ha}^{-1}$, corresponding to a proportion of 37 and $19 \%$ in the forage mass in the lower stratum, respectively.

The number of tillers per $\mathrm{m}^{2}$ was positively influenced by $\mathrm{N}$ rates and by inoculation (Figure 4). The increases obtained are attributed to the inclusion of additional nitrogen from both mineral source and biological fixation by bacteria through BNF, since the availability of $\mathrm{N}$ to the plant is fundamental for the survival and appearance of new tillers. The lowest number of tillers was verified in pastures where neither nitrogen nor inoculation were applied. In that case, the main stem is prioritized to the detriment of the tillers (Benin et al., 2012).

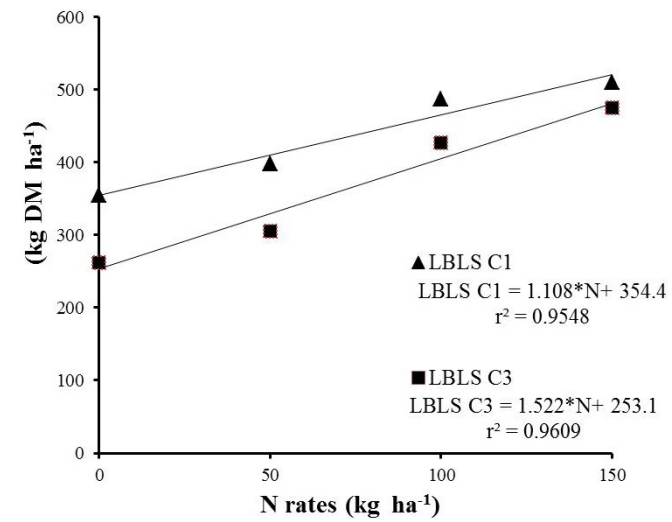

Figure 3: Forage mass in the lower stratum (FMLS) and leaf biomass in the lower stratum (LBLS) in the first (C1) and third (C3) cuttings. Agricultural years of 2016 and 2017. Santa Maria, RS. INOC = inoculated; NINOC = non-inoculated.
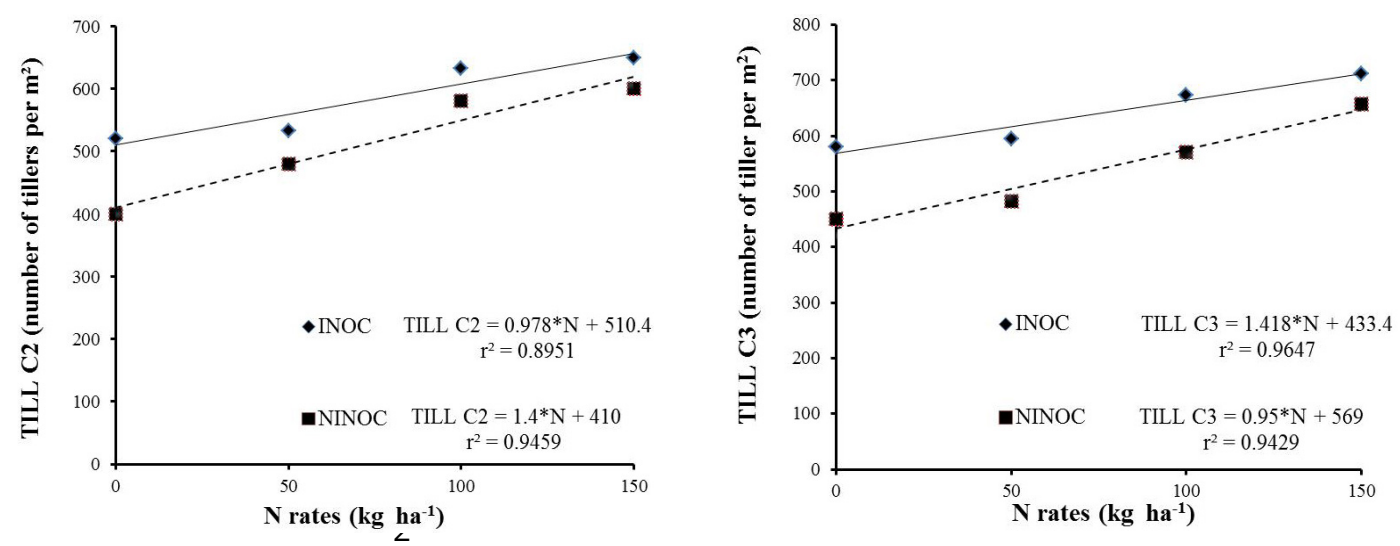

Figure 4: Number of tillers per $m$ in the second (TILL C2) and third (TILL C3) cuttings in dual-purpose wheat inoculated or not with Azospirillum brasilense and fertilized with increasing nitrogen rates. Agricultural years of 2016 and 2017. INOC = inoculated; NINOC = non-inoculated. 
Nitrogen rates and inoculation influenced forage yield (Figure 5) in all cuttings $(\mathrm{P}<0.05)$. For noninoculated wheat, a quadratic effect of $\mathrm{N}$ rates on forage yield was observed in the first cutting, reaching its peak at approximately $100 \mathrm{~kg} \mathrm{~N} \mathrm{ha}^{-1}$. For inoculated wheat, a linear regression model fitted to the data.

The quadratic effect obtained for non-inoculated seeds can be attributed to low precipitation index, since the cuttings started on July 07,2016 and July 29, 2017. In both years, the first cutting was preceded by below-normal precipitation in Santa Maria (Figure 1). Under these conditions, it is believed that the effect of bacteria on root development allowed the roots of inoculated plants to explore a larger area of soil and, consequently, to absorb more substantial amounts of water and nutrients (Dimpka; Weinand; Asch, 2009). Therefore, the use of inoculants has a synergistic effect on forage yield when associated with nitrogen fertilization, which is more efficient in stimulating the appearance of leaves and tillers (Díaz-Zorita; Canigia, 2009).
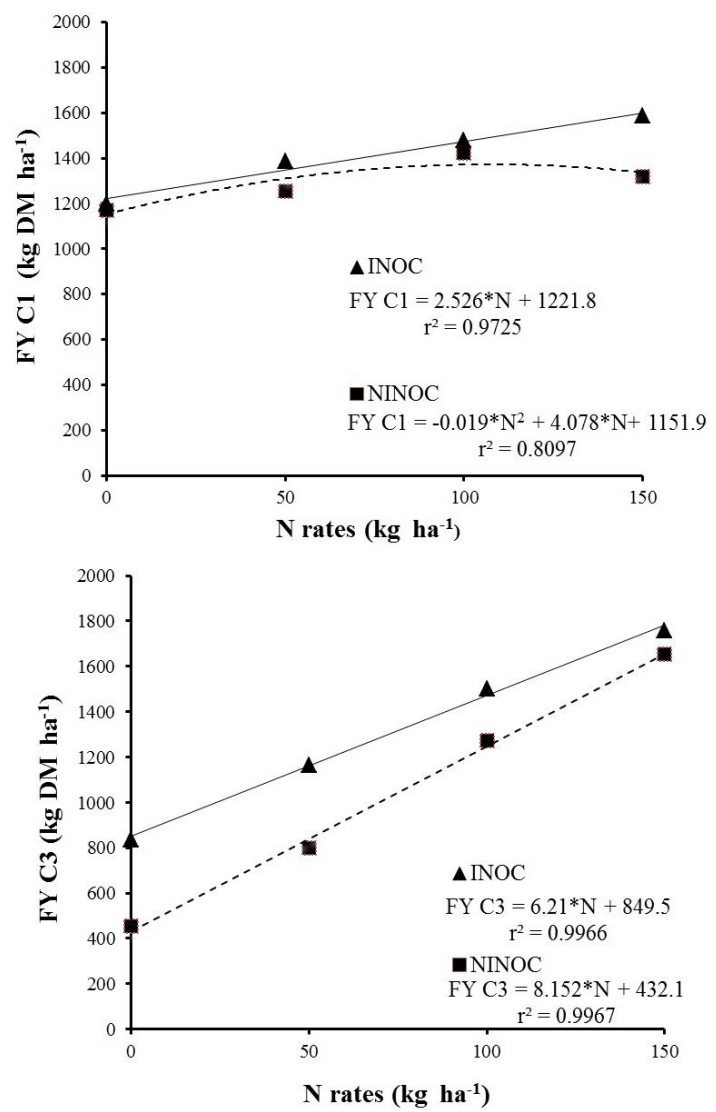

There was a linear increase in forage yield in the second and third cuttings, both for inoculated and noninoculated pastures. This result was already expected since there was a linear increase in leaf biomass in the upper stratum as a function of $\mathrm{N}$ rates (Figure 3 ). In each evaluation, the use of inoculation increased forage yield by approximately $20 \%$, which can be attributed to the increased proportion of tillers in the forage mass in pastures submitted to inoculation (Figure 4).

Although there was a linear increase in forage yield with increasing $\mathrm{N}$ rates in the second and third cuttings with inoculation, the effects were more expressive in wheat without fertilization and when $50 \mathrm{~kg} \mathrm{~N}^{-1}$ was applied. This result is related to the higher competitive capacity of $A$. brasilense under conditions of low nitrogen availability (Sylvia et al., 2005). Under these conditions, the synthesis of phytohormones beneficial to plant growth is increased. In addition, the biological $\mathrm{N}$ fixation is reduced at high ammonium concentrations $\left(\mathrm{NH}_{4}^{+}\right)$, derived from
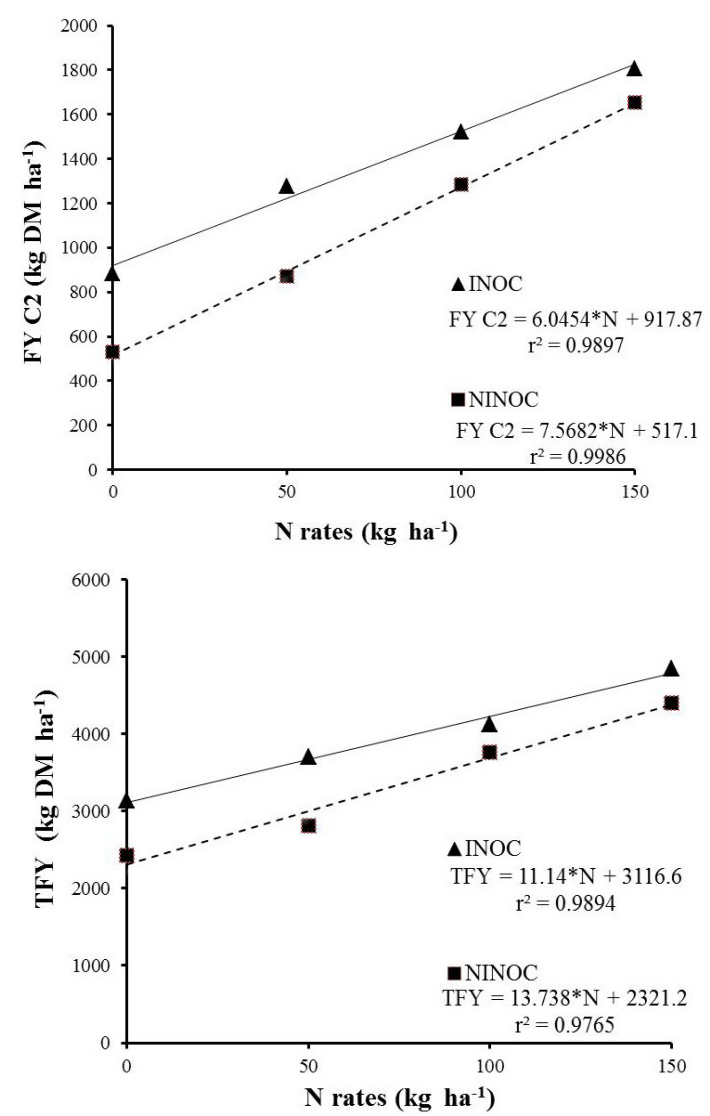

Figure 5: Forage yield in the first (FY C1), second (FY C2), third (FY C3) cuttings and total forage yield (TFY) in dual-purpose wheat inoculated or not with Azospirillum brasilense and fertilized with increasing nitrogen rates. Agricultural years of 2016 and 2017. INOC = inoculated; NINOC = non-inoculated. 
the hydrolysis of urea. This component causes rapid and reversible inhibition of nitrogenase activity, the enzyme responsible for the conversion of atmospheric nitrogen $\left(\mathrm{N}_{2}\right)$ into a form assimilable by plants $\left(\mathrm{NH}_{4}^{+}\right)$. This inhibition results in lower additional $\mathrm{N}$ inputs via $\mathrm{BNF}$ to inoculated plants when submitted to higher rates of nitrogen fertilization (Carvalho et al., 2014).

The inoculation led to an average increment of approximately 22, 24, 10 and $9 \%$ in total forage yield at fertilization rates of $0,50,100$ and $150 \mathrm{~kg} \mathrm{~N} \mathrm{ha}^{-1}$, respectively. This result is due to the increased proportion of leaf blades in inoculated pastures (Figure 2). The results of forage yield at $100 \mathrm{~kg} \mathrm{~N} \mathrm{ha}^{-1}$ are similar to those determined by Henz et al. (2016) when the BRS Tarumã was fertilized at $75 \mathrm{~kg} \mathrm{~N}$ $\mathrm{ha}^{-1}$ and managed under two cuttings (3660 kg of DM ha- $)$ in the northern region of Rio Grande do Sul.

Leaf biomass yield (Figure 6) was affected by both qualitative and quantitative factors, similarly to the results of forage yield. The correlation between total leaf biomass yield and forage yield $(\mathrm{r}=0.82, \mathrm{P}=0.0015)$ corroborates with this

association. Increases of leaf biomass yield approximately 42 , 28,21 and $15 \%$ in inoculated wheat pastures were observed at fertilization rates of $0,50,100$ and $150 \mathrm{~kg} \mathrm{~N} \mathrm{ha}^{-1}$, respectively. Increased proportion of leaf blades in forages is a desirable effect since they are the most nutritive fraction of forage. Furthermore, greater amounts of leaves facilitate the forage prehension by the animal, increasing the amount of forage consumed and, consequently, the animal performance (Rosa et al., 2013).

There was no effect of inoculation on the variables associated with grain yield. There was an effect of inoculation on forage mass, but it did not result in higher grain yield. This result can be attributed to the increased number of tillers in inoculated wheat, implying greater competition for photoassimilates for formation and maintenance of tissues (Pietro-Souza et al., 2013), even though there was no increase in grain yield. A similar response was also obtained in a study with dual-purpose wheat submitted to different $\mathrm{N}$ rates and inoculated with $A$. brasilense, wherein only the effect of fertilizer was verified (Silva; Pires, 2017).
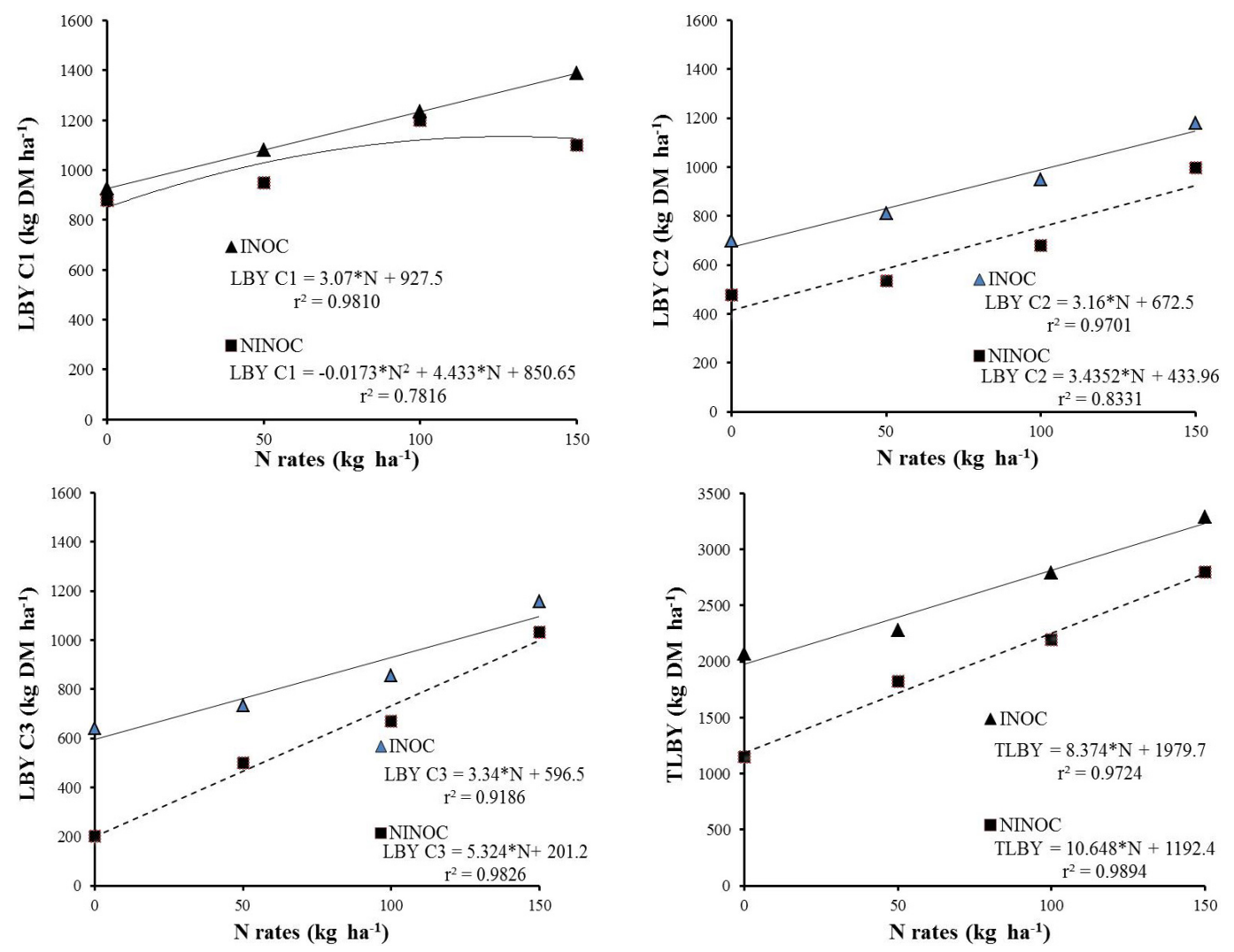

Figure 6: Leaf biomass yield in the first (LBY C1), second (LBY C2), third (LBY C3) cuttings and total yield (TLBY) in dual-purpose wheat inoculated or not with Azospirillum brasilense and fertilized with increasing nitrogen rates. Agricultural years of 2016 and 2017. INOC = inoculated; NINOC = non-inoculated. 
There was a linear effect in the mass of one thousand grains (Figure 7) with increasing $\mathrm{N}$ rates. This result is associated with increased production of photosynthetically active tissues in pastures where nitrogen fertilizer was applied, resulting in greater assimilation and subsequent
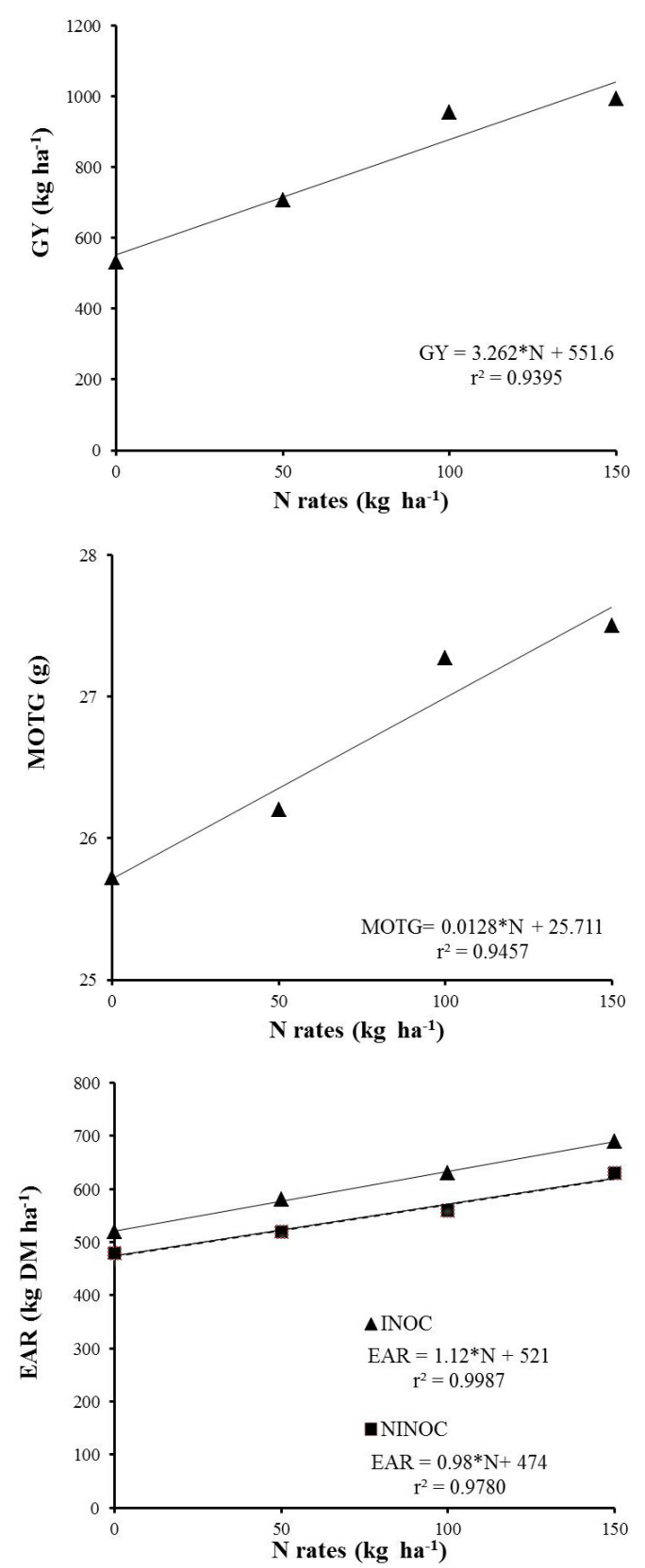

translocation of photoassimilates for grain formation (Benin et al., 2012). This assertion is confirmed by the correlation $(\mathrm{r}=0.61, \mathrm{P}=0.0072)$ between leaf biomass in the lower stratum (last cutting) and the mass of one thousand grains.
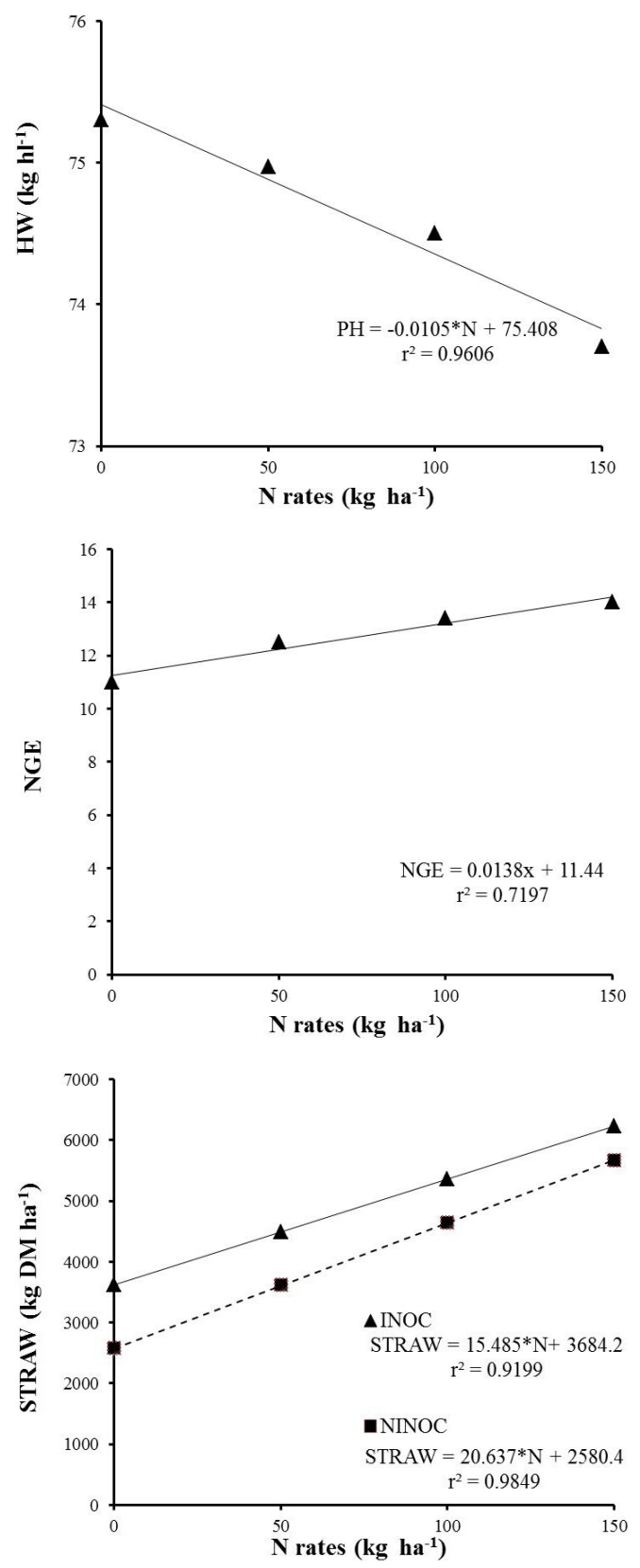

Figure 7: Grain yield (GY), hectoliter weight (HW), mass of one thousand grains (MOTG), number of grains per ear (NGE), number of ears per $\mathrm{m}^{2}$ (EAR) and straw yield (STRAW) in dual-purpose wheat inoculated or not with Azospirillum brasilense and fertilized with increasing nitrogen rates. Agricultural years of 2016 and 2017. INOC = inoculated; NINOC = non-inoculated. 
Grain yield linearly increased with increasing N rates. A similar response was observed for the number of ears per $\mathrm{m}^{2}$ and the number of grains per ear. These results are related to the supply of $\mathrm{N}$ to the crop during the transition from vegetative to reproductive buds (Espindula et al., 2010). The yield of non-fertilized wheat and the yield of wheat fertilized with $150 \mathrm{~kg} \mathrm{~N} \mathrm{ha}^{-1}$ reached 532 and 993 $\mathrm{kg} \mathrm{ha}^{-1}$, respectively. The values are considered low (Meinerz et al., 2012) and they can be attributed to the occurrence of precipitations and high temperatures (Figure 1) at the end of the crop cycle. These conditions favored the development of diseases such as the Fusarium head blight (Gibberella zeae) and blast (Pyricularia grisea) that reduced grain yield, even with the application of fungicides.

Hectoliter weight linearly reduced with increasing $\mathrm{N}$ rates, averaging $74.5 \mathrm{~kg} \mathrm{hl}^{-1}$. Similarly, Teixeira Filho et al. (2010) also verified that the HW values decreased when $\mathrm{N}$ rates were increased from 0 to $200 \mathrm{~kg} \mathrm{ha}^{-1}$. This result can be attributed to the greater competition for photoassimilates among grains, since the higher nitrogen availability increased the number of tillers, ears and grains per $\mathrm{m}^{2}$, consequently increasing the number of smaller grains. Therefore, the grains fit much better during HW measurement, reducing empty spaces between them. Thus, larger quantities of grains per unit of area imply a greater hectoliter weight.

There was a linear effect in straw yield with increasing $\mathrm{N}$ rates and inoculation. The higher $\mathrm{N}$ availability stimulated the tillering of wheat (Figure 3), implying the formation of a greater number of ears per $\mathrm{m}^{2}$, which after harvest produces more straw, consequently. This result can be confirmed by the correlations between straw yield and the number of tillers $(\mathrm{r}=0.65, \mathrm{P}=0.0054)$ and the number of ears $(\mathrm{r}=0.68, \mathrm{P}=0.0018)$.

The additional straw yield observed without nitrogen fertilizer (28\%) and at $150 \mathrm{~kg} \mathrm{~N} \mathrm{ha}^{-1}(10 \%)$ with inoculation can increase organic matter content, reduce surface temperature, retain more water, reduce density and minimize the incidence of invasive plants (Cherubin et al., 2014).

\section{CONCLUSIONS}

When associated with the tested nitrogen rates, seed inoculation with the bacterium Azospirillum brasilense (strains Ab-V5 and Ab-V6) increases the yields of forage, leaf biomass, straw and the number of tillers in BRS Tarumã dual-purpose wheat. Inoculation does not increase grain yield, hectoliter weight, grain mass and the number of grains per ear. Increasing $\mathrm{N}$ rates result in higher yields of both biomass and grains.

\section{REFERENCES}

ALVES, C. J. et al. Irrigated wheat subjected to inoculation with Azospirillum brasilense and nitrogen doses as top-dressing. Revista Brasileira de Engenharia Agrícola e Ambiental, 21(8):537-542, 2017.

BENIN, G. et al. Agronomic performance of wheat cultivars in response to nitrogen fertilization levels. Acta Scientiarum. Agronomy, 34(3):275-283, 2012.

BRYANT, R. H.; GREGORINI, P.; EDWARDS, P. G. R. Effects of $\mathrm{N}$ fertilisation, leaf appearance and time of day on $\mathrm{N}$ fractionation and chemical composition of Lolium perenne cultivars in spring. Animal Feed Science and Technology, 173(1):210-219, 2012.

CARVALHO, T. L. G. et al. Nitrogen signalling in plant interactions with associative and endophytic diazotrophic bacteria. Journal of Experimental Botany, 65(19):5631-5642, 2014.

CHERUBIN, M. R. et al. Desempenho agronômico do milho em sucessão a espécies de cobertura do solo sob sistema plantio direto no Sul do Brasil. Global Science and Technology, 7(1):76-85, 2014.

CONFORTIN A. C. C. et al. Diferentes massas de forragem sobre as variáveis morfogênicas e estruturais de azevém anual. Ciência Rural, 43(3):496-502, 2013.

COSTA, R. R. G. F. et al. Efficiency of inoculant with Azospirillum brasilense on the growth and yield of second-harvest maize. Pesquisa Agropecuária Tropical, 45(3):304-311, 2015.

DÍAZ-ZORITA, M.; FERNANDEZ-CANIGIA, M. V. Field performance of a liquid formulation of Azospirillum brasilense on dryland wheat productivity. European Journal of Soil Biology, 45(1):3-11, 2009.

DIMPKA, C.; WEINAND, T.; ASCH, F. Plant-rhizobacteria interactions alleviate abiotic stress conditions. Plant Cell Environment, 32(12):1682-1694, 2009.

ESPINDULA, M. C. et al. Doses e formas de aplicação de nitrogênio no desenvolvimento e produção da cultura do trigo. Ciência e Agrotecnologia, 34(6):1404-1411, 2010.

FERREIRA, J. P. et al. Azospirillum brasilense via foliar e doses de nitrogênio em cobertura na cultura do trigo na região de Itapeva-SP. Brazilian Journal of Biosystems Engineering, 11(2):154-163, 2017.

GALINDO, F. S. et al. Wheat yield in the Cerrado as affected by nitrogen fertilization and inoculation with Azospirillum brasilense. Pesquisa Agropecuária Brasileira, 52(9):794805, 2017. 
HENZ, E. L. et al. Dual purpose wheat production with diferent levels of nitrogen topdressing. Semina: Ciências Agrárias, 37(2):1091-1100, 2017.

HUNGRIA, M. et al. Inoculation with selected strains of Azospirillum brasilense and A. lipoferum improves yields of maize and wheat in Brazil. Plant and Soil, 331(1-2):413425, 2010.

MARTIN, T. N. et al. Fitomorfologia e produção de cultivares de trigo duplo propósito em diferentes manejos de corte e densidades de semeadura. Ciência Rural, 40(8):16951701, 2010.

MEINERZ, G. R. et al. Produtividade de cereais de inverno de duplo propósito na depressão central do Rio Grande do Sul. Revista Brasileira de Zootecnia, 41(4):873-882, 2012.

MOREIRA, F. M. S. et al. Bactérias diazotróficas associativas: Diversidade, ecologia e potencial de aplicações. Comunicata Scientiae, 1(2):74-99, 2010.

PAVINATO P. S. et al. Production and nutritive value of ryegrass (cv. Barjumbo) under nitrogen fertilization. Revista Ciência Agronômica, 45(2):230-237, 2014.

PICCININ G. G. et al. Rendimento e desempenho agronômico da cultura do trigo em manejo com Azospirillum brasilense. Revista Agrarian, 6(22):393-401, 2013.

PICCININ, G. G. et al. Efficiency of seed inoculation with Azospirillum brasilense on agronomic characteristics and yield of wheat. Industrial Crops and Products, 43(1):393397, 2013.

PIETRO-SOUZA, W. et al. Desenvolvimento inicial de trigo sob doses de nitrogênio em Latossolo Vermelho de Cerrado. Revista Brasileira de Engenharia Agrícola e Ambiental, 17(6):575-580, 2013.

ROSA, A. T. N. et al. Consumo de forragem e desempenho de novilhas de corte recebendo suplementos em pastagem de azevém. Ciência Rural, 43(1):126-131, 2013.

SILVA, S. R.; PIRES, J. L. F. Resposta do trigo BRS Guamirim à aplicação de Azospirillum, nitrogênio e substâncias promotoras do crescimento. Revista Ciência Agronômica, 48(4): 631-638, 2017.

SOIL SURVEY STAFF. Keys to Soil Taxonomy. 12ed. USDANatural Resources Conservation Service, Washington, DC, USA, 2014.

SYLVIA, D. M. et al. Principles and applications of soil microbiology. New Jersey: Prentice Hall, 2005. 640p.

TEIXEIRA FILHO, M. C. M. et al. Doses, fontes e épocas de aplicação de nitrogênio em trigo irrigado em plantio direto. Pesquisa Agropecuária Brasileira, 45(8):797-804, 2010.

ZAMAN, M. et al. Evaluating the use of plant hormones and biostimulators in forage pastures to enhance shoot dry biomass yield by perennial ryegrass (Lolium perenne L.). Journal of the Science of Food and Agricultural, 96(1):715-726, 2016. 